\title{
メタン・空気混合気の希薄燃焼における「ゆらぎ」の解析*
}

\author{
門 脇 敏*1, 貫 井 純一郎*2
}

\section{Analysis on the Fluctuation in the Lean Burn of Methane-Air Mixtures}

\author{
Satoshi KADOWAKI*3 and Jun-ichiro NUKUI \\ ${ }^{* 3}$ Nagaoka University of Technology, Department of Mechanical Engineering, \\ Kamitomioka, Nagaoka-shi, Niigata, 940-2188 Japan
}

\begin{abstract}
This paper deals with the flame shape and fluctuation in the lean burn of methane-air mixtures. Cellular flames are formed on a flat burner at low equivalence ratios, and the cell size becomes larger as the equivaence ratio becomes lower. We measure the fluctuation of brightness of premixed flames, and obtain the RMS and power spectrum density of the brightness fluctuation. With a decrease in the equivalence ratio, the RMS of the brightness fluctuation increases. This is because the diffusivethermal effect has a destabilizing influence at low equivalence ratios. The power spectrum density has sharp peaks, whose frequency corresponds to the oscillation frequency of premixed flames, and the $1 / \mathrm{f}$ spectrum appears in low frequency range. Moreover, we perform the time series analysis on the brightness fluctuation. We obtain the attractor, correlation dimension, Lyapunov exponent to investigate the characteristics of the fluctuation of premixed flames. The characteristics of fluctuation depend strongly on the equivalence ratio, i.e., on the intrinsic instability of premixed flames. The results suggest that the fluctuation analysis is applicable to the diagnostics of flame instability.
\end{abstract}

Key Words: Premixed Combustion, Lean Burn, Fluctuation, Time Series, Intrinsic Instability, Cellular Flame

\section{1. 䊰}

近年の環境問題に対する意識の高まりの中で，天 然ガスの主成分であるメタンの希薄然焼が注目されて いる. その理由は, 他の炭化水素系燃料の燃焼と較心゙ 単位発熱量当たりの二酸化炭素排出量が最も少ないこ と, 並びに, 燃焼温度の低下により排気ガス中の窒素 酸化物濃度が非常に低くなることである. メタン・空 気混合気の希薄然焼は, 環境負荷の低减に直接結ひ付 くので，今後益々盛んに用いられると考えられる.

メタンは空気より軽いので，その希薄然焼におい て，火炎は不安定になり易いことが知られている(1) (3). この不安定性は，主に拡散・熱的効果と流体力学的効 果に起因している(4). そして，これらの不安定要因は， 火炎の形状やその挙動と密接に関連している. これま

\footnotetext{
* 原稿受付 2005 年 3 月 14 日.

*1 正員, 長岡技術科学大学工学部 (正940-2188 長岡市上富岡 町 1603-1).

*2 長岡技術科学大学大学院工学研究科.

E-mail : kadowaki@mech.nagaokaut.ac.jp
}

でに，予混合火炎の不安定性について，実験的(5) 〜 (8), 理論的(9) (11), 及ひ数值的(12) (15)手法を用いた数多くの 研究がなされてきた. そして, 火炎形状や火炎挙動に 及ぼす不安定要因の影響が詳細に調べられ，そのメ力 ニズムが明らかにされている.

予混合火炎の固有不安定性は，火炎挙動に大きな影 響を与えるので，火炎の「ゆらぎ」とも密接な関連が ある. 従って，この関連性を明らかにすることが出来 れば，固有不安定性が火炎挙動に与える影響を「ゆら ぎ」解析のみから把握することが可能になる。つまり， 「ゆらぎ」解析による火炎不安定性の診断が可能にな る. また，種々の燃焼形態にこの診断手法を適用する ことが出来れば, 別の角度からの燃焼現象の把握に役 立つと考えられる.この様に, 予混合火炎の固有不安 定性と「ゆらぎ」の関連性を明確にすることは，重要 から有用であり，その応用範用は広いと思われる. し かしこれまでにこれれらの関連性に着目した研究は， ほとんどなされていない. 
そこで，本研究では，メタン・空気混合気の希薄 燃焼を取り扱い，火炎からの発光の照度变化を測定し， 火炎の「ゆらぎ」を解析する. 周波数解析, 並びに, カ才ス時系列解析で用いられている手法を採用して,

「ゆらぎ」の特性を調べる，そして，固有不安定性と 「ゆらぎ」の関連性を明らがする。

\section{2. 実験装置おょび実験方法}

図 1 は, 本研究で使用している実験装置の概略図 を示したものである. 平面バーナー（LAVISION） の上流側で混合されたメタン（純度 $99.99 \%$ ) と乾燥 空気の混合気が，バーナ一下部から流入する. 直径 $60 \mathrm{~mm}$ の多孔質板上に，セル状または平面状の予混 合火炎が形成される，混合気の流量は 35e/min一定と し, 当量比 $\phi$ は $0.64 \sim 1.00$ とする.

平面バーナー上の火炎は，ディジタルカメラ (FUJIFLM Fine Pix 4900Z，192 万画素，シャッタ

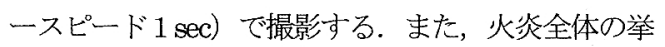
動を把握するために，ディジタルビデオカメラ

（SONY DCR-IP220K，108 万画素）の「Night Shot」 機能を用いて，火炎及びその下流部からの赤外 線を感知し，火炎下流側高温部の挙動を撮影する.

火炎の「ゆらぎ」の測定には, フォトダイオード （浜松ホトニクス $\mathrm{S} 1223-01$, 受光面 $3.6 \times 3.6 \mathrm{~mm}$, 感度波長範囲 $320 \sim 1100 \mathrm{~nm}$, 最大感度波長 $960 \mathrm{~nm}$ ）を用いる. フォトダイオードの前方に干渉 フィルター (光伸光学工業 BWBE 431 , 形状 $\phi 20 \times$ 4.5 , 最大透過波長 $431.0 \mathrm{~nm}$, 半值幅 $4.5 \mathrm{~nm}$ ）を置き, $\mathrm{CH}$ 発光を受光する. 火炎加の $\mathrm{CH}$ 発光の照度変化 を電流変化として取り出し, 電流／電王変換アンプ (浜松ホトニクス $\mathrm{C} 2719$, 遮断周波数 $1.6 \mathrm{kHz}, \mathrm{V} / \mathrm{A}$ $\left.=10^{9}\right)$ を介してデー夕収集装置 (KEYENCE NR2000, A/D 変換分解能 14bit）に取り込むs. サンプリ ング周波数は $500 \mathrm{~Hz}$ ，測定時間は 262.144sec である. 発光强度の測定值をその平均值で標淮化した $\mathrm{y}(\mathrm{t})$ に 対して, 二乗平均值 (RMS) , パワースペクトル, 及び交差率分布 (CRD) を求める. また，力オス時 系列解析で用いられている手法を採用し，「ゆらぎ」 をカオスカ学の観点から調べる(16)(17). また, 相関次元 と最大リアプノフ指数を求め, 得られるアトラクター の幾何学的な構造とその軌道不安定性を明らかにする.

\section{3. 实験結果および考察}

$3 \cdot 1$ 火资形状 平面バ一十上形成されるメ夕 ン・空気予混合火炎の直接写真 $(\phi=0.64,0.74$,

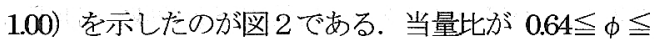
0.74 の領域では，セル状の火资が形成され，当量比が 小さくなると共にセルのサイズは大きくなる.また， $0.74<\phi \leqq 1.00$ の領域では, 平面状の火炎が形成され る.こえは，固有不安定性の主な要因である抗散・熱 的効果 (物質拉散と熱伝導の相互作用によるもので, 不足成分の物質搪散の影響が勝る場合，火炎の不安定 化に寄与する）が，小さい当量比において顕著に表れ るためと考光られる(中).

$3 \cdot 2$ 発光強度の時間変動 火炎の「ゆらぎ」の特 性を調べるために，発光強度の時間变動を解析する. 標準化した発光強度の時間变化 $\mathrm{y}(\mathrm{t})$ とその二乗平均 值 (RMS) を示したのが，図3と図4である.なお， これらの值は，フォトダイオードの設置場所を変えて 測定を行っても，ほとんじ変わらない，セル状火炎が 形成される $0.64 \leqq \phi \leqq 0.74$ の領域では，当量比が小さ くなると共に「ゆらぎ」の強さは大きくなる.このこ とは，拡散・熱的効果が「ゆらぎ」に多大の影響を与 えていることを示している。，一方，平面火炎が形成さ れる領域では, 当量比が変化しても「ゆらぎ」の強さ に大きな変化は見られない．

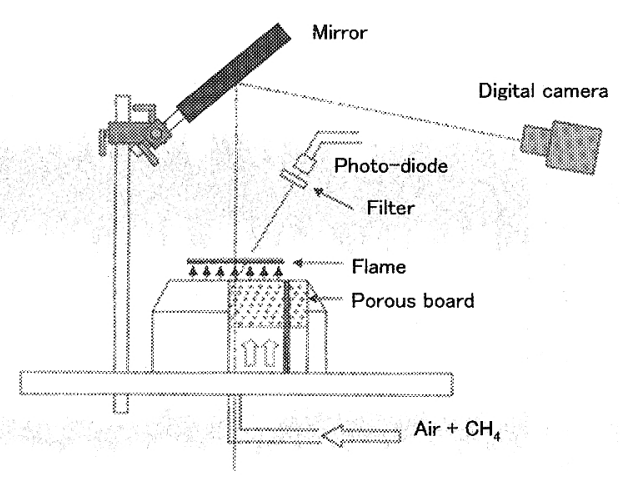

Fig. 1 Experimental apparatus

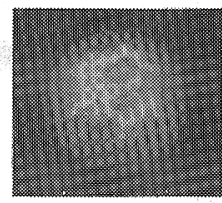

$\phi=0.64$

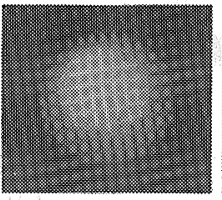

$\phi=0.74$

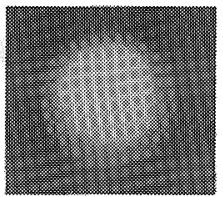

$\phi=1.00$
Fig. 2 Cellular and planar flames 
図5は， $\phi=0.64 ， 0.74 ， 1.00$ における $\mathrm{y}(\mathrm{t})$ のパワ 一スペクトル P を示したものである. 全ての場合に おいて, パワースペクトルは低周波数領域で周波数 $\mathrm{f}$ の逆数に比例している. 本実験でも「1/f ゆらぎ」 (18)(19) が観察されている. さらに, 矢印で示した $2 つ$ のピークが $\mathrm{f}_{1}$ と $\mathrm{f}_{2}$ で生じている. つまり，「ゆら ぎ」は複数の強い周波数成分を保持している. このと き, $\mathrm{f}_{2}$ は $\mathrm{f}_{1}$ の 2 倍の周波数と一致しているので, $\mathrm{f}_{2}$ は $\mathrm{f}_{1}$ の調和周波数に対応するものと考えられる. ま た，火炎下流側の高温部をディジタルビデオカメラで 撮影し，その挙動をビデオに納めた. そして，火炎下 流側高温部の変動周波数が $\mathrm{f}_{1}$ とほぼ等しくなること を確認した.このことから，火炎の「ゆらぎ」は，高 温燃焼ガスと周囲空気との対流が主な要因であると考 えられる. そして, この要因に火炎形状や固有不安定 性の効果が付加して, 火炎は摇らいでいると思われる.

次に, $\mathrm{y}(\mathrm{t})$ の交差率分布 (CRD) を求める. 不規 則ノイズの解析において, 交差率分布はノイズの位相 情報を捉えるものとして知られている(19). 交差率分布 は，ある一定のレベルを変動波形が正の方向に単位時 間に横切る回数であり, 次の式により与えられる.

$$
\mathrm{CRD}(\xi)=\mathbf{n}(\xi) / \mathrm{T}
$$

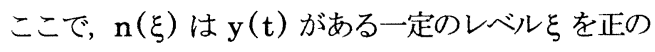

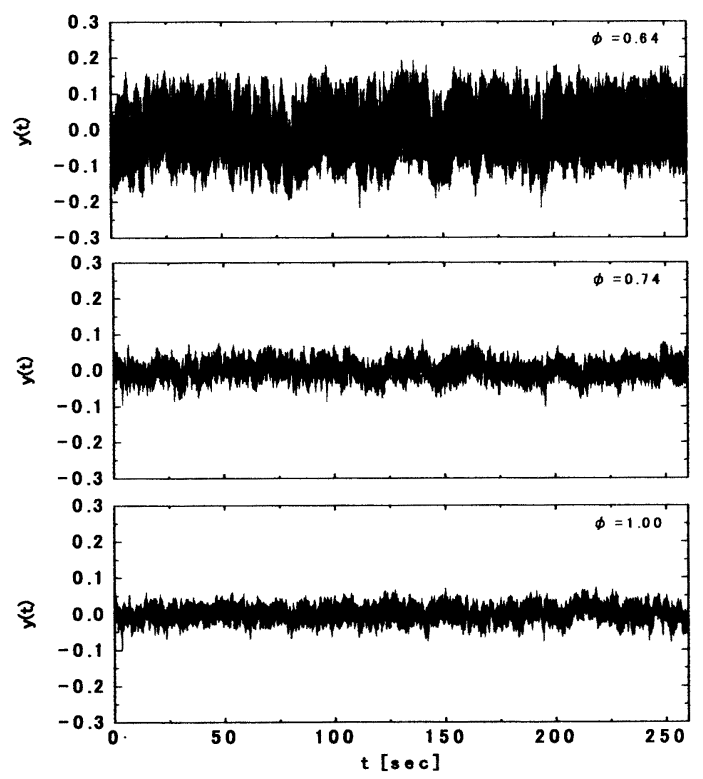

Fig. 3 Normalized brightness intensity

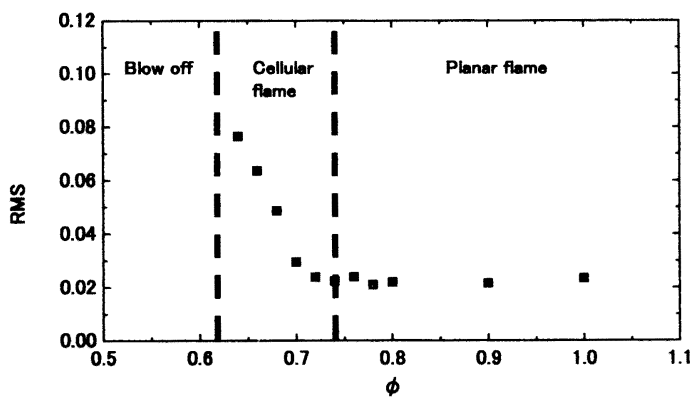

Fig. 4 Root mean square of the brightness fluctuation

a.

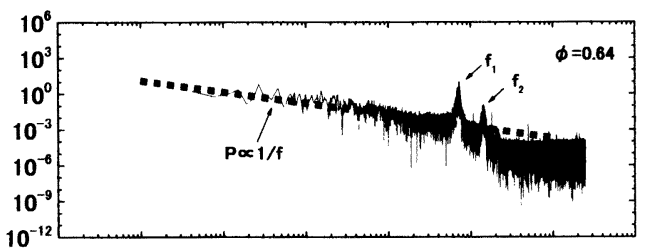

a

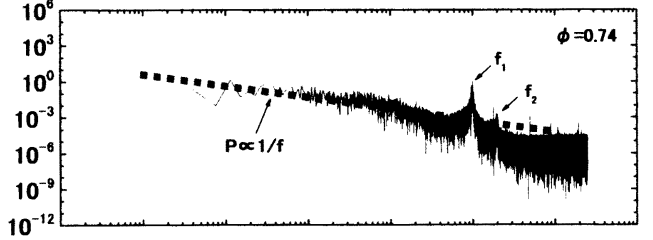

a

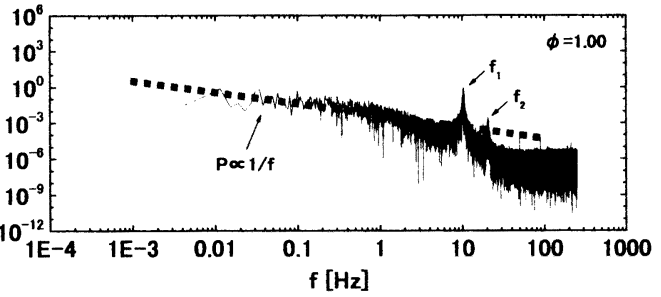

Fig. 5 Power spectrum density of the brightness fluctuation

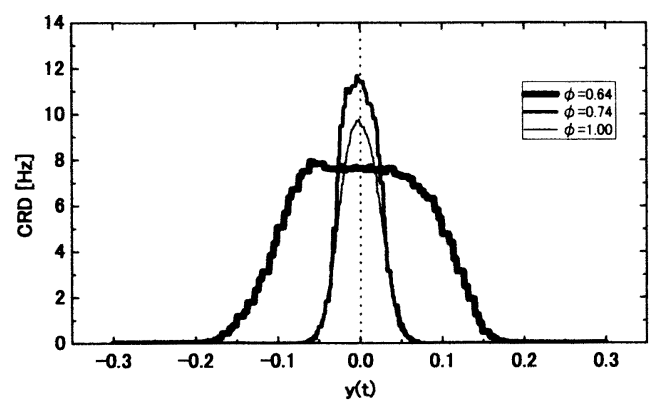

Fig. 6 Crossing rate distribution of the brightness fluctuation 
方向に横切る回数， $\mathrm{T}$ は測定時間である. 図6は， $\phi$ $=0.64 ， 0.74,1.00$ における CRD を示したものであ る. $\phi=0.74$ における CRD の最大值は， $\phi=1.00$ に おけるそれより僅かに大きいが，全体の分布形状はほ ぼ同じであり，対称性を保持している，一方， $\phi=$ 0.64 における CRD は前者らと大きく異なり, CRD の最大值は小さく, その幅は広くなっている. そして, 分布形状は対称性をやや失っている. これは, 当量比 が小さくなると共にセル状火资の挙動がよりダイナミ ックになるためと考えられる.

3-3 カオス時系列解析 波形信号 $\mathbf{y}(\mathrm{t})$ に対して, カオス時系列解析で用いられている手法を適用し,

「ゆらぎ」をカオスカ学の観点から調べる.

$3 \cdot 3 \cdot 1$ アトラクターの再權成 本実験で得られ る一変数の時系列データ（発光強度の時間変動）を用 いて, 高次元空間のアトラクターを再構成する. アト ラクターの再構成には, Takens の埋め込み定理(16)を 採用する. 遅九時間 $\tau$ を用い， $\mathrm{m}$ 次元の遅延座標にお いて構成される $\mathrm{m}$ 次元ベクトル

$$
\mathrm{v}(\mathrm{t})=(\mathrm{y}(\mathrm{t}), \mathrm{y}(\mathrm{t}+\tau), \ldots, \mathrm{y}(\mathrm{t}+(\mathrm{m}-1) \tau))
$$

を生成して, アトラクターを再構成する.ここでは, 再構成状態空間の次元（埋め込み次元）を $\mathrm{m}=3$ とす る. また，遅れ時間は， $\tau=1 / 4 \mathrm{f}_{1}$ とする.

図 7 は， $\phi=0.64 ， 0.74 ， 1.00$ におけるアトラクタ 一を示したものである. 全てのアトラクターは, ドー ナツ状の形を有している. 準周期的な現象で見られる これらのアトラクターの形状は, 当量比と密接な関係 がある. 平面火炎 $(0.74<\phi \leqq 1.00)$ が形成される領 域では, アトラクターの形状はほぼ同じである. セル 状火炎が形成され始める $\phi=0.74$ では，アトラクタ 一全体の大きさは平面火炎のそれとほとんど変わらな
いが，中心にある穴の径はやや小さくなる. このこと は，軌道がやや不安定になることを示している，さら に当量比が小さくなると，アトラクター全体が大きく なる. そして，アトラクターの穴の径は大きくなり， その形状はより明膫になる. これは, 波形信号 $\mathrm{y}(\mathrm{t})$ の振幅が大きくなり，火炎の摇らぎ方がより周期的に なるためと考えられる.

$3 \cdot 3 \cdot 2$ フラクタル次元解析 アトラクターの幾 何学的な構造を調べるために, フラクタル次元を求め る. これまでに, フラクタル次元推定法として様々な 手法が提案されているが，ここでは $\mathrm{G}-\mathrm{P}$ 法(20)を採用 する.この手法は, 相関積分と呼ばれる二点間距離の 累積頻度関数を計算し，フラクタル次元の一つである 相関次元を求めるものである. 相関積分は次式で定義 される.

$$
C^{m}(r)=\lim _{N \rightarrow \infty} \frac{1}{N^{2}} \sum_{\substack{i, j=1 \\ i \neq j}}^{N} I(r-|v(i)-v(j)|)
$$

ここで, $\mathrm{N}$ は自然数, $\mathrm{r}$ は $\mathrm{m}$ 次元超球の半径である. また, I $(\mathrm{s})$ はへビサイドの関数で, $\mathrm{s} か ゙$ 正または零の とき $1, \mathrm{~s}$ が負のとき 0 である. 得られた相関積分が， 次式のようにスケーリングされたとき，

$$
C^{m}(r) \propto r^{\gamma(m)}
$$

スケーリング指数 $\gamma(\mathrm{m})$ )が相関指数である. 再構成 状態空間の次元（埋め込み次元）を上げながら相関指 数を計算する. 実際のアトラクターの次元より埋め込 み次元が大きくなると, $\gamma(\mathrm{m})$ はある一定の值に漸近 する. その值が相関次元である. なお，信号が完全に ランダムな場合，相関指数は一定值に漸近せず，埋め 込み次元と共に単調に増加する。
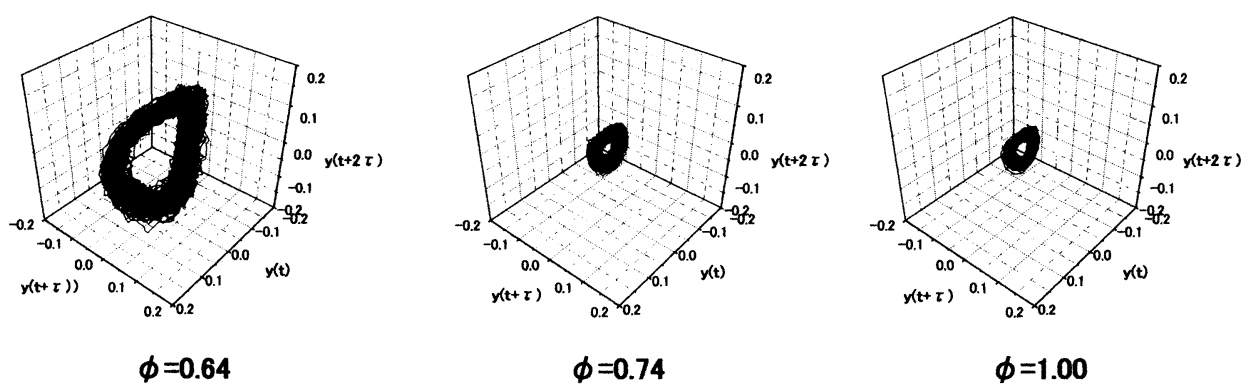

Fig. 7 Attractor of the brightness fluctuation 
図 8 は, $\phi=0.64$ における相関積分と超球半径の 関係を両対数グラフにプロットしたものである.この とき，埋め込み次元は $\mathrm{m}=1$ 10である. 適当な $\mathrm{r}$ の 範囲内における直線部分の傾きが相関指数である. 図 9 は, $\phi=0.64,0.74,1.00$ における相関指数之埋め 込み次元の関係を示したものである. 埋め込み次元が 大きくなると，相関指数はある一定の值に漸近する. 図から得られる相関次元は， $\phi=0.64,0.74,1.00$ に おいて, $\mathrm{Dc}=1.6,2.4,2.0$ である.

\section{$3 \cdot 3 \cdot 3$ リアプノフスペクトラム解析 複雑な振} 舞を示す時系列データを解析する際には, フラクタル 次元解析のみではなく, アトラクターの力学的な構造 を定量化するリアプノフスペクトラム解析を行う必要 がある. ここでは, 最大リアプノフ指数を求め, 再構 成状態空間におけるアトラクターの軌道不安定性を調 べる. 最大リアプノフ指数を推定する方法として, Wolf らの手法(21)を採用する. 時間 $\mathrm{t}_{0}$ におけるアトラ クターの軌道上の点を $\mathrm{y}\left(\mathrm{t}_{0}\right)$ とする. アトラクター 上より $\mathrm{y}\left(\mathrm{t}_{0}\right)$ の近傍を探索して最も近い点を $\mathrm{y}^{\prime}\left(\mathrm{t}_{0}\right)$ とし, これら 2 点間の長さを $\mathrm{L}\left(\mathrm{t}_{0}\right)$ とする. 次に, 時間 $\mathrm{t}_{1}$ における 2 点 $\mathrm{y}\left(\mathrm{t}_{1}\right)$ と $\mathrm{y}^{\prime}\left(\mathrm{t}_{1}\right)$ との間の長さを $\mathrm{L}^{\prime}\left(\mathrm{t}_{1}\right)$ とし, 軌道の拡大率: $\mathrm{L}^{\prime}\left(\mathrm{t}_{1}\right) / \mathrm{L}\left(\mathrm{t}_{0}\right)$ を求める. このとき, 時間間隔: $\mathrm{t}_{1}-\mathrm{t}_{0}$ は, アトラクターの 1 周期分の時間 : 1 / f，と一致させる. この様な操作を 次々と繰り返して行い，次式を計算することで最大り アプノフ指数入 [1/s] を推定することができる.

$$
\lambda=\frac{1}{t_{M}-t_{0}} \sum_{k=1}^{M} \log \frac{L^{\prime}\left(t_{k}\right)}{L\left(t_{k-1}\right)}
$$

ここで, $\mathrm{M}$ と kは自然数である.

本実験における最大リアプノフ指数は， $\phi=0.64$, $0.74,1.00$ のとき, $\lambda=0.08,0.33,0.15[1 / \mathrm{s}]$ であ る. なお, 最大リアプノフ指数は, 当量比に対して連 続的に変化し, $0.64 \leqq \phi \leqq 0.74$ の領域では当量比が大 きくなると共に増加し， $0.74<\phi \leqq 1.00$ の領域では减 少する. $\phi=0.74$ の最大リアプノフ指数が $\phi=1.00$ のそれより大きいのは, 拡散・熱的効果によりアト ラクターの軌道が不安定になるためと考えられる. 当量比がさらに小さくなると, $\lambda$ の值は小さくなる, つまり，火炎の摇らぎ方は規則的になる. この結果 は, 固有不安定性により「ゆらぎ」の振幅は大きくな るが, アトラクターはリミットサイクルに近くなり, 摇らぎ方はより周期的になることを示している. その 原因として，火炎面が有限な曲率をもつことにより，

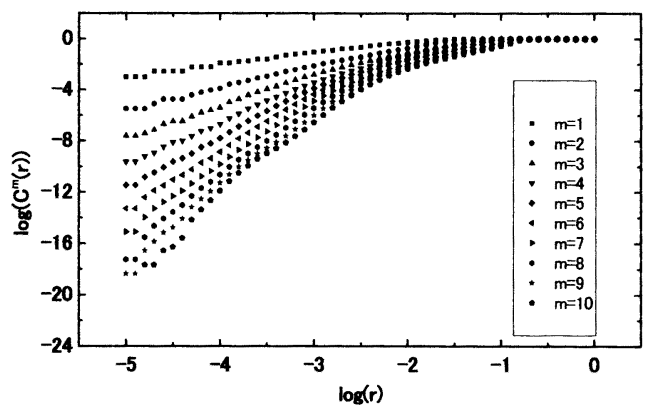

Fig. 8 Correlation integral

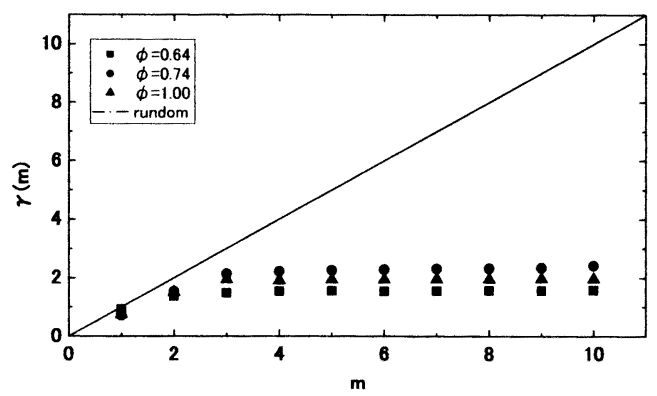

Fig. 9 Correlation exponent

「ゆらぎ」の周期成分以外が相対的に小さくなること が考えられる.

\section{4. 結諭および今後の課顆}

メタン・空気混合気の希薄然焼を取り扱い，火炎形 状を調べ，火炎の「ゆらぎ」解析を行った. 周波数解 析, 並びに, カ才ス時系列解析で用いられている手法 を採用して，「ゆらぎ」の特性を調べ，そのカオス的 な振舞を考察した. そして，以下の1）～4）の結論 を得た。

1）平面バーナ一上には， $0.74<\phi \leqq 1.00$ の領域で 平面状の火炎が形成され， $0.64 \leqq \phi \leqq 0.74$ の領域でセ ル状の火炎が形成される. そして, 当量比が小さくな ると共に，セルのサイズは単調に大きくなる.

2）平面状の火炎が形成される $0.74<\phi \leqq 1.00$ の領 域では，「ゆらぎ」の強さはほとんよ゙変化しないが, セル状の火炎が形成される $0.64 \leqq \phi \leqq 0.74$ の領域では, 当量比が小さくなると共に単調に大きくなる. 
3）「ゆらぎ」のパワースペクトルは，低周波数領 域において周波数の逆数に比例している, つまり, 本 実験でも「1/fゆらぎ」が観察されている.また，火 炎の変動周波数と一致する周波数において,パワース ペクトルにピークが生じている.

4）火炎の「ゆらぎ」には，カ才ス的な振舞が見ら れる. そして，アトラクターは，当量比が小さくなる と大きくなる. また, 相関次元と最大リアプノフ指数 は， $0.64 \leqq \phi \leqq 0.74$ の領域では当量比が大きくなると 共に増加し, $0.74<\phi \leqq 1.00$ の領域では減少する. 拡 散・熱的効果は当量比と密接な関係があるので，「ゆ らぎ」と固有不安定性には，強、関連性があることに なる.この結果は，「ゆらぎ」解析が火炎不安定性の 診断に適用可能なことを示唆している.

本研究では，メタンの希薄然焼を取り扱ったが，水 素の希薄燃焼やプロパンの過濃燃焼においても，同様 の現象が生じると予想される. 特に, 次世代燃料とし て期待されている水素の希薄然焼では，拡散・熱的効 果が大きく作用するので，より顕著な現象が観察され ると思われる. このテーマは, 本研究の今後の重要な 課題であると考えられる.

\section{碀 辞}

本研究を遂行するにあたり，科学研究費補助金（基 盤研究 $\mathrm{C}-2$ ）の支援を受けた。ここに謝意を表する.

\section{文献}

(1) Bregeon, B., Gordon, A., and Williams, F. A., Combust. Flame, 33 (1978), 33-45.

(2) Izumikawa, M., Mitani, T., and Niioka, T., Combust. Flame, 73 (1988), 207-214

(3) Gorman, M., el-Hamdi, M., and Robbins, K. A., Combust. Sci. Technol., 98 (1994), 37-45.

（4）Williams, F. A. (柘植俊一監訳), 燃焼の理論, (1987), 305385 , 日刊工業新聞社.

(5) Markstein, G. H., J. Aeronaut. Sci., 18 (1951), 199-209.

(6) Hertzberg, M., Prog. Energy Combust. Sci., 15 (1989), 203-239.

(7) Clanet, C. and Searby, G., Phys. Rev. Lett., 80 (1998), 3867-3870.

(8) Qin, X., Kobayashi, H., and Niioka, T., Exper. Thermal Fluid Sci., 21 (2000), 58-63.

(9) Clavin, P., Prog. Energy Combust. Sci., 11 (1985), 1-59.
(10) Sivashinsky, G. I., Philos. Trans. R. Soc. London A, 332 (1990), 135-148.

(11) Kadowaki, S., Phys. Fluids, 7 (1995), 220-222.

(12) Patnaik, G. and Kailasanath, K., Combust. Flame, 99 (1994), 247-253

(13) Denet, B. and Haldenwang, P., Combust. Sci. Technol., 104 (1995), 143-167.

(14) Bychkov, V. V., Golberg, S. M., Liberman, M. A., Kleev, A I., and Eriksson, L. E., Combust. Sci. Technol., 129 (1997), 217-242.

(15) Kadowaki, S., Suzuki, H., and Kobayashi, H., Proc. Combust. Inst., 30 (2004), 169-176.

（16）合原一幸編, カオス時系列解析の基礎と応用, (2000), 13198, 産業図書.

(17) Gotoda, H. and Ueda, T., Proc. Combust. Inst., 29 (2002), 1503-1509.

（18）武者利光, 応用物理, 54 (1985), 429-435.

（19）藤原・清澤, 電学論 C, 117 (1997), 69-74.

(20) Grassberger, P. and Procaccia, I., Phys. Rev. Lett., 50 (1983), 346-349.

(21) Wolf, A., Swift, J. B., Swinney, H. L., and Vastano, J. A, Physica D, 16 (1985), 285-317. 